\title{
Humulus lupulus L. as a Natural Source of Functional Biomolecules
}

\author{
Gonzalo Astray ${ }^{1}$, Patricia Gullón ${ }^{2}$, Beatriz Gullón ${ }^{3}$, Paulo E. S. Munekata ${ }^{4}$ and \\ José M. Lorenzo $4,5, *$ (D) \\ 1 Department of Physical Chemistry, Faculty of Science, University of Vigo (Campus Ourense), As Lagoas, \\ 32004 Ourense, Spain; gastray@uvigo.es \\ 2 Nutrition and Bromatology Group, Department of Analytical and Food Chemistry, Faculty of Food Science \\ and Technology, University of Vigo, Ourense Campus, 32004 Ourense, Spain; pgullon@uvigo.es \\ 3 Department of Chemical Engineering, Faculty of Science, University of Vigo (Campus Ourense), As Lagoas, \\ 32004 Ourense, Spain; bgullon@uvigo.es \\ 4 Centro Tecnológico de la Carne de Galicia, Rúa Galicia No 4, Parque Tecnológico de Galicia, \\ San Cibrao das Viñas, 32900 Ourense, Spain; paulosichetti@ceteca.net \\ 5 Área de Tecnología de los Alimentos, Facultad de Ciencias de Ourense, Universidad de Vigo, \\ 32004 Ourense, Spain \\ * Correspondence: jmlorenzo@ceteca.net
}

Received: 30 June 2020; Accepted: 21 July 2020; Published: 23 July 2020

check for updates

\begin{abstract}
Hops (Humulus lupulus L.) are used traditionally in the brewing industry to confer bitterness, aroma, and flavor to beer. However, in recent years, it has been reported that female inflorescences contain a huge variety of bioactive compounds. Due to the growing interest of the consumers by natural ingredients, intense research has been carried out in the last years to find new sources of functional molecules. This review collects the works about the bioactive potential of hops with applications in the food, pharmaceutical, or cosmetic industries. Moreover, an overview of the main extraction technologies to recover biomolecules from hops is shown. Bioactivities of hop extracts such as antibacterial, antifungal, cardioprotective, antioxidant, anti-inflammatory, anticarcinogenic, and antiviral are also summarized. It can be concluded that hops present a high potential of bioactive ingredients with high quality that can be used as preservative agents in fresh foods, extending their shelf life, and they can be incorporated in cosmetic formulation for skincare as well.
\end{abstract}

Keywords: hop; emerging extraction technologies; bioactivities; functional molecules

\section{Introduction}

The common hop plant (Humulus lupulus L.) is a hardy and dioecious vine whose aerial part is herbaceous and annual, while the rootstock is perennial, and it can create adventitious roots every year [1]. It is a species of the genus Humulus that belongs to the Cannabaceae family whose genus origin could be China [2]. It can be found principally in European and in Western Asia deciduous forests and thickets, and in other zone areas with a temperate climate [3]. Hops were cultivated in Babylon around 200 A.D. [4], and they have been in ongoing use for centuries (even a millennium) mainly as a beer ingredient [5]. In the European Union, the main producer is Germany, registering for 2018 a production of 41,792 tons for a total of 57,239 tons from the member states [6]. The hop cones are the most utilized portion of this plant [2]; nevertheless, there are parts such as the young shoots or asparagus that can be eaten in different Mediterranean countries [7].

In the last decades, the biological benefits of plants, traditionally used in folk and/or traditional medicine, have been explored by the scientific world [5,8]. In this sense, besides their use in the brewing industry, traditionally hop cones have been applied with medical purposes for the control 
of the spasms, anxiety, fever, inflammation, activation of the gastric function, and the treatment of sleeping disorders, among others [2,9]. Indeed, hops present numerous benefits for human health due to their antibacterial, antifungal, cardioprotective, antioxidant, anti-inflammatory, anticarcinogenic, and antiviral bioactivities [2,5,9-13].

The female inflorescences (called hop cones or simply hops) as well as other parts of the plant (leaves, stems, and rhizomes) are rich in different biologically active molecules as polyphenolic compounds and acyl phloroglucides, which are responsible for the different health-promoting effects and bioactivities [3,9]. The lupulin glands, which present a yellow-green color, are located on the hop umbel (in the inner and outer bracteoles) and contain bitter resins and aroma substances [1]. The secondary metabolites of the female inflorescences (presented in the lupulin glands) can be divided into three groups: (1) the hop resins, (2) the hop oil, and (3) the hop polyphenols [14]. The levels of the aromatic essential oil and the bitter hop $\alpha$ - and $\beta$-acids depend on several factors such as the variety or ripening stage and even on climatological conditions [15]. The main use of hops worldwide, around $97 \%$, is used for brewing purposes [16] to add bitterness, aroma, and taste to the beer.

Taking the above into account, and the current trend of searching natural compounds with novel biological properties, the wealth of the hop in bioactive compounds makes it an excellent source to extract biologically active molecules with multiple applications in the alimentary, pharmaceutical, and nutraceutical industries $[12,15,17-20]$. This has promoted intense research in the field of bioactive compounds from hops that allows on the one hand achieving high yields and on the other hand keeping the bioactivities of the extracted compounds. For this, the selection of adequate extraction technology as well as the appropriate solvent is fundamental.

In this context, many publications related to the isolation of the active compounds have been developed over the past decades [5]. Several isolation technologies are well established using conventional (organic) solvents [5,21]; nevertheless, their residual levels must be controlled [21], because they can remain in the final product and have detrimental health effects [5]. According to Marriott [21], EU legislation and organic certification bodies establish the allowed extraction solvents, their maximum residue levels, and further restrictions, respectively. To overcome the shortcomings of the conventional solvents [22], eco-friendly solvents such as natural deep eutectic ones represent a safer alternative, and their use has increased in the last decades [23]. Moreover, the use of emerging technologies such as (1) ultrasound-assisted extraction (UAE), (2) microwave-assisted extraction (MAE), (3) pressurized liquid extraction (PLE), and/or (4) supercritical fluid extraction (SFE) has increased in the last decade [24-28]. These approaches open new alternatives in the design of the extraction process of more efficient of biocompounds from natural biomass within the framework of Green Chemistry [23].

In light of the above and encouraged by the growing interest in hops due to their significant potential as a source of bioactive compounds, this review collects the studies about the use of hops as a natural source of these biocompounds. Aspects related to the different current extraction methods applied in the recovery of phytochemicals from hop as well as the evaluation of their different bioactivities are reviewed. Moreover, the applications of these compounds in different fields such as pharmaceutical, nutraceutical, and cosmetic are also summarized.

\section{Main Components}

The hop cones have different components, such as (1) resins, (2) essential oils, (3) proteins, and (4) polyphenols, among others $[16,29,30]$. The classification of hop cone compounds is shown in Figure 1. Some of these phytochemicals are briefly described next. 


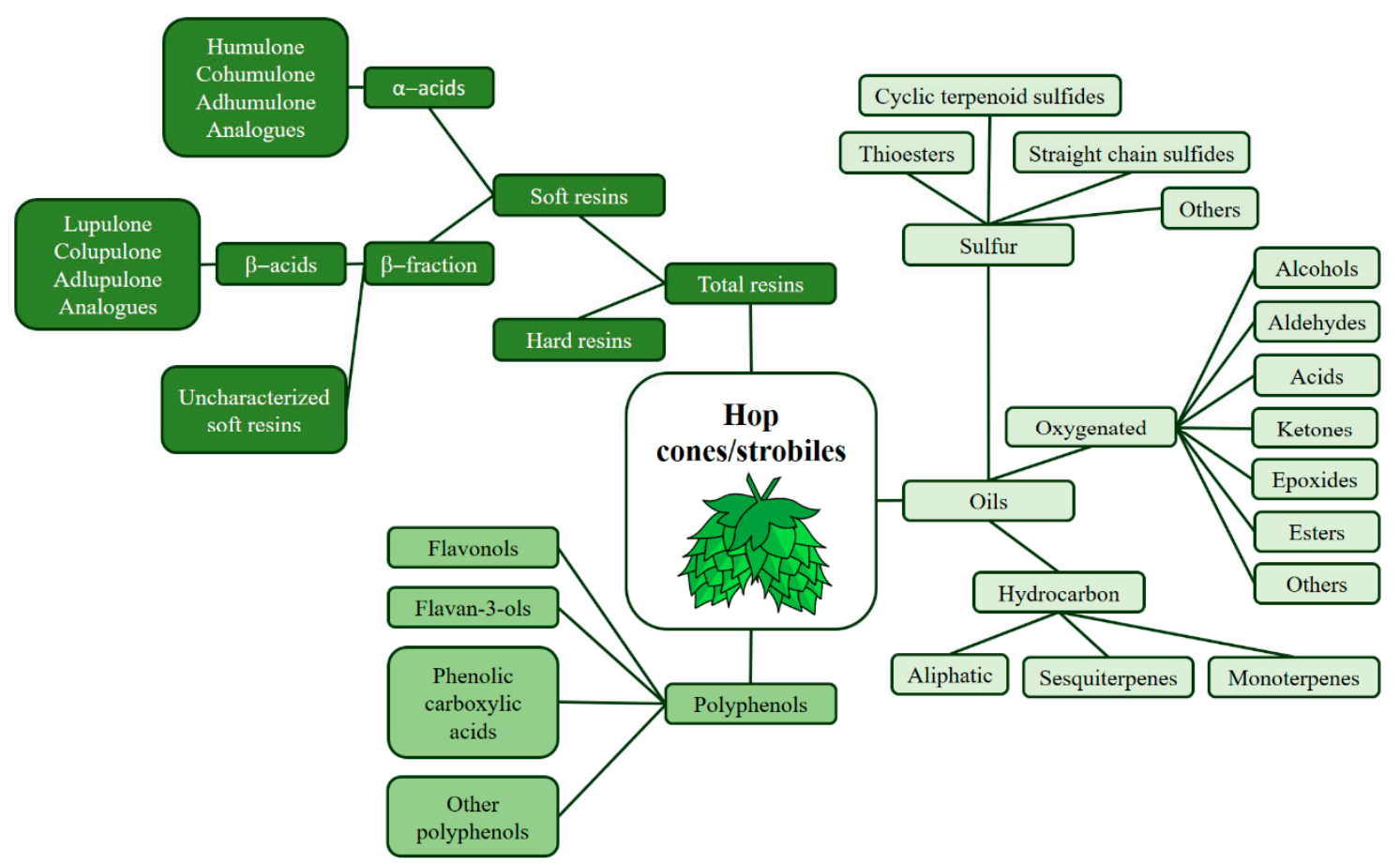

Figure 1. A brief classification of hops cone compounds based on the reviewed literature [16,29,31-36].

\subsection{Hop Resin}

The resins are hop plant secondary metabolites that can be solubilized in cold methanol and diethyl ether $[14,16]$. The total resins can be divided into two kinds: soft and hard resins [1,14,16,37], and they are characterized by their solubility and insolubility in hexane, respectively [14,16]. According to Almaguer et al. [16], the soft resin content in whole hop cones is high compared to the hard resin; in fact, soft resins range within 10-25\%, while the hard resins comprise between $3 \%$ and $5 \%$ of the total weight of dried hops. The soft resins are formed by two different bitter acids: $\alpha$-acids (between $3 \%$ and $17 \%$ ) and $\beta$-acids (between $2 \%$ and $7 \%$ ) [1]. There is a third group, uncharacterized components, that together with $\beta$-acids form the $\beta$-fraction $[16,38]$. The $\alpha$-acids have five components: humulone, cohumulone, adhumulone, prehumulone, and posthumulone [1,15]. The first three are the majority, and the prehumulone and posthumulone are the minority [15]. In the same way, $\beta$-acid has another five homologs (lupulones) [1,15]. Depending on the hop variety, cultivation conditions, and climate, the content of these substances homologs may vary greatly [5]. Moreover, the hop resins could suffer from different changes in the storage with the oxidation start of the $\alpha$-acids and $\beta$-acids; due to this process, these acids would decrease during the storage [16]. It is commonly accepted that hard resins can from the oxidation of the soft resins (although it is not yet well defined) [16]. During the traditional brewing process, raw hops are added to the boiling wort, and $\alpha$-acids are isomerized to iso- $\alpha$-acids [15], which are the main compounds responsible for the bitter taste of beer [15,39].

\subsection{Hop Oil}

Essential oils are secondary metabolites exuded in the lupulin glands $[14,16]$, and they are called essentials because they provide the hops with their distinctive smell and transfer their aroma and flavor to beer [16]. Essential oils account for $0.5-3 \%$ of the dried hops, with over 400 different compounds identified in the hop oil fraction [16]. Their components would be divided into three huge groups: (1) hydrocarbons, (2) oxygenated, and (3) sulfur [5,16]. According to the bibliography compiled by Almaguer et al. [16], different families of molecules such as aliphatic, monoterpenes, and sesquiterpenes are present in the first group, the second group contains alcohols, aldehydes, acids, 
and esters, among others, and finally, the sulfur group is constituted by thioesters and cyclic terpenoid sulfides, among others.

The hydrocarbon fraction is the most abundant (between $50 \%$ and $80 \%$ of total oil) and the most abundant compounds from this fraction are monoterpenes $\alpha$ - and $\beta$-pinene and myrcene, among others [12]. According to the authors [12], the oxygenated fraction represents $30 \%$ of the total oil, being a complex mixture of different compounds such as aldehydes or ketones, among others. The main compounds studied from this fraction are linalool or geraniol, among others [12]. The sulfur fraction is present in small quantities in the essential oil of hops (up to 1\%). These compounds have potent aromas and low odor thresholds, so they play a key role in the overall flavor of beer $[12,16]$.

\subsection{Hop Polyphenols}

Polyphenols are a wide group of biologically active secondary metabolites $[14,16]$ whose content and profile depend on the hop variety as well as the different climatic conditions of cultivation $[3,16]$. The cone bract presents the greatest content of polyphenols in the hop plant, and their content in the cone can fluctuate between $4 \%$ and $14 \%$ (dry matter) [40]. The hop polyphenols can be grouped into (1) flavonols, (2) flavan-3-ols, (3) phenolic carboxylic acids, and (4) other polyphenolic compounds [16,36]. The most abundant flavonols, according to its content, are quercetin and kaempferol, and among the dominant flavan-3-ols, (+)-catechin, (-)-epicatechin, and (+)-gallocatechin stand out, as well as their polymers proanthocyanidins and condensed tannins $[12,16]$. Ferulic acid is the most representative compound of the group of phenolic carboxylic acids [12,16]. Other phenolic compounds that are unique to hop inflorescences are multifidol glucosides (phloroglucinol derivatives with prenyl side chains) and prenylflavonoids (xanthohumol, isoxanthohumol, desmethylxanthohumol, and 6- and 8-prenylnaringenin) [5,12]. Numerous efforts have been developed to produce hop extracts with high polyphenolic content due to their possible use as natural additives (antioxidant and/or antimicrobial) in industrial applications [5].

\section{Extraction Techniques}

The extraction efficiency of the plethora of phytochemicals that can be obtained from hops is highly dependent on the extraction technology applied. These methods must be fast, versatile, easy to use, environmentally friendly, cost-effective, and be able to both extract with high yields and keep the quality of the target compounds [28]. The extraction techniques used for the recovery of bioactive compounds range from (1) the conventional methods to innovative technologies such as (2) ultrasound-assisted extraction, (3) microwave-assisted extraction, (4) pressurized liquid extraction, and (5) supercritical fluid extraction, including the use of green solvents as deep eutectic solvents (DES).

\subsection{Conventional Methods}

Solid-liquid extraction (SLE) and steam distillation have been applied for extracting bioactive compounds from hops. For this purpose, several organic solvents such as ethanol, methanol, methylene chloride, ethyl acetate, acetone, hexane, and their mixtures with water have been used. The extraction efficiency is greatly affected by the type and polarity of the solvent, the experimental conditions of time and temperature, and the extraction number of cycles [41]. Several phytochemicals have been extracted from hops using conventional methods. For instance, hydrodistillation was applied to extract essential oils from the cone powder, obtaining a yield of $6.3 \mathrm{~mL} / \mathrm{kg}$ of dry cones [10]. Using gas chromatography coupled to mass spectrometry (GC-MS/MS), the authors identified the presence of 16 compounds, of which myrcene, trans-caryophyllene, and $\alpha$-humulene were the three main components of hops essential oil [10]. In another study, Jeliazkova et al. [42] evaluated the yield and compound profile of essential oil extracted from whole hop cones via steam distillation using a sequential elution. The results indicated that $83.2 \%$ of the oil was extracted during the first hour, in comparison with control performed during 4-h noninterrupted distillation [42]. Furthermore, the 
profile of eluted compounds was also significantly different, observing that monoterpenes were eluted before sesquiterpenes.

The effect of four organic solvents with different polarities (ethylene chloride, acetone, ethyl acetate, and methanol) on the recovery of flavonoids from spent hops was studied by Bartmańska et al. [43]. According to their results, the increase of polarity of the extractant improved the efficacy of extraction, obtaining the highest yield with methanol $(92.95 \mathrm{~g} / \mathrm{kg})$. The authors found that the most abundant extract compound was xanthohumol, and they indicated that the highest efficiency and selectivity to recover this compound from spent hops was ethyl acetate $(3.51 \mathrm{~g} / \mathrm{kg})$ and the solvent, which led to the lowest extraction yield being methylene chloride $(1.33 \mathrm{~g} / \mathrm{kg})$ [43]. In hydroalcoholic extracts obtained by maceration from hop cones, two main groups of compounds were identified by reverse phase HPLC-UV: prenylated chalcones and acylphloroglucinol derivatives [10].

Prencipe et al. [44] indicated that the dynamic maceration of hops with $\mathrm{MeOH}-\mathrm{HCOOH}$ (99:1, $v / v$ ) led to the best result in terms of hop components recovery, specifically prenylflavonoids and bitter acids, in comparison with other methods including heat-reflux extraction, microwave, or ultrasound.

Although the application of organic solvents is widespread in industrial extraction processes, their employment presents some inconveniences related to health risk and environmental pollution, limiting their use in the recovery of bioactive compounds [27]. Due to this, a new method of solvents generation known as deep eutectic solvents (DESs) has been applied in the last decade as a promising green alternative substitution for conventional organic solvents in the recovery of biomolecules [27]. In this line, Lakka et al. [23] tested the ability of a eutectic mixture composed of glycerol and L-alanine to extract polyphenols from hops. In this study, the authors applied a response surface methodology (RSM) based on a Box-Behnken design for the optimization of process parameters (DES concentration in aqueous mixtures ( $\mathrm{C}_{\mathrm{DES}}: 55-85 \% \mathrm{w} / \mathrm{w}$ ), liquid-to-solid ratio (LSR: $20-60 \mathrm{~mL} / \mathrm{g}$ ), and speed of stirring $\left.\left(\mathrm{S}_{\mathrm{S}}: 200-800 \mathrm{rpm}\right)\right)$. Under the optimized extraction conditions $\left(\mathrm{C}_{\mathrm{DES}}=85 \%(w / w), \mathrm{LSR}=59 \mathrm{~mL} / \mathrm{g}\right.$ and $\mathrm{S}_{\mathrm{S}}=688 \mathrm{rpm}$ ), a theoretically optimal yield of total polyphenols of $118.97 \mathrm{mg}$ gallic acid equivalents (GAE)/g dm was obtained [23].

\subsection{Emerging Extraction Technologies}

The efficient recovery of valuable compounds from different bioresources largely depends on the technology used for their extraction. Conventional extraction methods present various disadvantages associated with the high consumption of solvents, prolonged extraction times, and degradation of thermosensitive biomolecules. To avoid operational hazards and the presence of harmful solvent traces in the extract material, novel alternative extraction techniques have been explored to meet the demand of greener processes to extract and fractionate the different hop valuable components (even to valorize the hop-exhausted solid) [15].

\subsubsection{Ultrasound-Assisted Extraction (UAE)}

Ultrasound has been identified for its potential use in the phytopharmaceutical extraction industry [45]. The UAE system is an uncomplicated, economical, and efficient alternative to the extraction methods used traditionally that can improve extraction yield, extraction rates, or the recovery of heat-sensitive compounds [46]. This kind of technique uses high-frequency waves that promote the formation of bubbles in the medium, leading to the formation of the cavitation phenomenon [47]. The implosion of these bubbles disrupts the cellular structure and facilitates the diffusion of the solvent into the cellular plant tissue, which increases mass transfer and consequently improves the extraction [47]. The efficiency of the UAE is influenced by various operating parameters such as the type and concentration of the solvent, sonication time, temperature, LSR, ultrasonic power, and frequency, which must be optimized to reach high extraction yields [48]. To give an example, Almeida et al. [49] applied a Central Composite Rotational Design (CCRD) to optimize the recovery of phytochemicals with antioxidant capacity from Brazilian hops. The authors evaluated the effect of three extraction parameters: temperature $\left(33-67^{\circ} \mathrm{C}\right), \mathrm{EtOH}$ concentration $(43-77 \%)$, and LSR (17-33 mL/g) on the total 
phenolic content (TPC). According to the results of regression analysis, the LSR was the parameter that showed a greater influence on TPC of the extracts, while the temperature and the concentration of ethanol had a lesser effect. Under optimized extraction conditions $\left(52{ }^{\circ} \mathrm{C}, 49 \%\right.$ ethylic alcohol and LSR of $34 \mathrm{~mL} / \mathrm{g}$ ), a TPC of $33.93 \mathrm{mg} \mathrm{GAE} / \mathrm{g}$ for Brazilian hops was obtained. Moreover, the authors compared Brazilian hop extracts with those obtained with the same variety of hops grown in the USA. The results showed that the Brazilian hops showed a higher content of phenols and flavonoids and better antioxidant potential analyzed by the ABTS (2,2'-azino-di(3-ethylbenzothiazoline-6-suslfonic acid) and DPPH ( $\alpha, \alpha$-Diphenyl- $\beta$-picrylhydrazyl) tests compared to the USA hops.

In another study, the UAE has been applied with success for the extraction of diverse types of biocompounds from hops. For example, Muzykiewicz et al. [3] used this technique with different extractants (methyl, ethyl, and isopropyl alcohol) under three different concentrations to assess the total phenolic content and the antioxidant activity. This research was carried out using fresh hop leaves from different harvested years (2017 and 2018). Process parameters were fixed at $40 \mathrm{kHz}$ during different times $(15,30$, and $60 \mathrm{~min})$ at room temperature and under different solvent concentrations $(40 \%, 70 \%$ and $96-99.5 \%(v / v))$. The authors reported that the extracts (from young hop leaves harvested at the starting vegetation) presented a high antioxidant activity, and this antioxidant potential was influenced by different factors (including the solvent type or extraction time) and concluded that the most effective process was using undiluted methanol during one hour of ultrasound-assisted extraction. The antioxidants content depends on the harvesting time and can be also influenced by climatic conditions, among other environmental elements [3].

\subsubsection{Microwave-Assisted Extraction (MAE)}

In the last decade, the use of microwave-assisted extraction (MAE) to recover active molecules from several natural sources, including hops, has also been addressed. This extraction technique is based on the application of microwave energy, which is converted into heat mainly through two mechanisms, which are ionic conduction and dipole rotation [48]. This process increases the pressure and temperature inside the cell matrix, which causes the rupture of the cell structure, improving the release of the desired compounds. MAE has been recognized as a promising green technique over conventional extraction methods since it presents various advantages, including (1) shorter extraction time, (2) minor energy input, (3) decreased solvent consumption, (4) ease of operation, and (5) a minimum degradation of bioactive compounds $[28,48]$.

Tyśkiewicz et al. [50] explored the use of microwave-assisted hydrodistillation (MAHD) to extract essential oils from hops $\mathrm{scCO}_{2}$ (sc: supercritical) extract, and the results were compared with those obtained using conventional hydrodistillation (HD). Under optimized conditions (335 W microwave power at LSR of 8:3), MAHD yielded 3.77\% of essential oils in an extraction time of $30 \mathrm{~min}$, while with conventional HD, only $1.90 \%$ was reached using a longer time (276 $\mathrm{min})$. The results of quantitative analyses of $\beta$-myrcene and $\alpha$-humulene of the obtained oil by MAHD were $77.36 \%$ and $9.47 \%$, respectively.

\subsubsection{Pressurized Methods}

Another interesting technique is the pressurized liquid extraction (PLE), which is also named accelerated solvent extraction (ASE) or pressurized hot water extraction (PHWE) when water is used [51]; also, pressurized solvent extraction (PSE) presents important benefits compared to conventional extractions [52].

Formato et al. [53] studied the efficiency of cyclically pressurized solid-liquid extraction using a Naviglio Extractor for the recovery of acidic compounds from hops flowers in comparison with supercritical fluid extraction (SFE). The results showed that the cyclically pressurized solid-liquid extraction was more effective for the extraction of $\alpha$ acids and iso- $\alpha$-acids, while SFE exhibited a greater potential for the isolation of $\beta$ acids. The authors concluded that both technologies can be used to 
obtain high yields of hops extracts, confirming the possibility of adjusting the experimental parameters of both methods to make it selective for specific kinds of compounds.

Gil-Ramírez [51] assessed the suitability of PHWE for the selective extraction of isoxanthohumol (IX) against xanthohumol (XN) from hops. Water extraction was performed using $1500 \mathrm{psi}$ at $150^{\circ} \mathrm{C}$ and an extraction time of $30 \mathrm{~min}$ ( $5 \mathrm{~min}$ per cycle for 6 cycles). Ethanol extraction at $150{ }^{\circ} \mathrm{C}$ during $30 \mathrm{~min}$ ( 5 min per cycle for 6 cycles) was carried out for comparative purposes. Besides, sequential extractions were performed using a solvent in increasing polarity order (hexane, ethanol, and water). Based on the results, PHWE showed high selectivity toward isoxanthohumol against xanthohumol ( $2.34 \mathrm{mg} / \mathrm{g}$ and $0.11 \mathrm{mg} / \mathrm{g}$, respectively, with a ratio IX/XN of 21) in comparison with PLE using EtOH as a solvent, after using hexane $(5.15 \mathrm{mg} / \mathrm{g}$ and $2.57 \mathrm{mg} / \mathrm{g}$, respectively, with a IX/XN ratio of 2) [51].

PSE has been proposed to extract $\alpha$-acids and $\beta$-acids from hops and hop products [52]. The authors studied the sample preparation method influence and the parameters that affect the extraction efficiency to find an alternative method to the EBC 7.7 extraction method (used for bitter acids determination in hop products) to save time and facilitate the laborious extraction. The most important parameters were optimized (1) temperature, (2) extraction solvent type, (3) process of sample preparation, and (4) number of cycles. The PSE method saved solvent, it was less arduous and time-consuming, and according to the statistical evaluation carried out by the authors, the developed PSE process can be considered comparable to the EBC 7.7 extraction method.

\subsubsection{Supercritical Fluid Extraction (SFE)}

Another emerging technology that has been advantageously positioned for the green extraction of heat-sensitive biocompounds is supercritical fluid extraction (SFE). $\mathrm{CO}_{2}$ is widely used for SFE due to it being low toxic, non-flammable, inexpensive (compared to organic solvents), and recyclable. According to Hrnčič et al. [5], new opportunities using unconventional supercritical solvents have been appeared such as SF6 or noble gases (or their mixtures), although supercritical $\mathrm{CO}_{2}$ remains as the more used solvent for these operations. However, $\mathrm{CO}_{2}$ is intrinsically non-polar; thus, to improve the extraction of polar compounds such as phenolic compounds, it requires the addition of polar cosolvents (modifiers) such as ethanol or methanol [28]. Formato et al. [53] evaluated the extractive efficiency of SFE- $\mathrm{CO}_{2}$, with or without a cosolvent, to extract the acidic compounds contained in hops flowers. The results revealed that the use of supercritical $\mathrm{CO}_{2}$ with cosolvent improved the performance of $\alpha$ acids (28.3\%) compared to pure $\mathrm{CO}_{2}$ (21.5\%). In contrast, the highest yield in $\beta$ acids $(46.2 \%)$ was found in the extracts obtained with supercritical $\mathrm{CO}_{2}$ versus $37.5 \%$ for $\mathrm{SFE}-\mathrm{CO}_{2}$ with ethanol.

SFE has been applied successfully for the selective isolation of bitter acids from two hop cultivars (Hallertau Magnum and Herkules) [54]. The authors identified, by HPLC analysis, the presence of two main groups of molecules: $\alpha$-acids (55.2 $w / w$ and $46.9 w / w$ in the Herkules and Hallertau Magnum hops, respectively) and $\beta$-acids (18.3 $w / w$ and $22.9 w / w$, respectively) [54]. Cohumulone accounted $38.7 \%$ of $\alpha$-acids in Herkules hops and $24.9 \%$ in Hallertau Magnum hops, and the colupulone was the major component of $\beta$-acids, reaching $57.2 \%$ and $44.2 \%$ in Herkules and Hallertau Magnum, respectively [54].

To valorize the spent hops, Jackowski et al. [55] proposed their use as a raw material for the recovery of xanthohumol. Under $80^{\circ} \mathrm{C}$ and 850 bar, a yield of $1.23 \%$ of xanthohumol was obtained.

Some studies about the extraction technologies of different phytochemicals from hops are presented in Table 1. 
Table 1. Extraction technologies for obtaining active molecules from hops

\begin{tabular}{|c|c|c|c|c|c|}
\hline Matrix & Target Compound & Method & Extraction Conditions & Outcomes & Reference \\
\hline Hops & $\begin{array}{c}\text { Essential oil } \\
\text { (desmethylxanthohumol, } \\
\text { xanthohumol, } \\
\text { co-humulone, lupulone, } \\
\text { co-lupulone, and } \\
\text { lupulone) }\end{array}$ & Maceration & $\begin{array}{l}\text { Extraction with ethanol: } \mathrm{H}_{2} \mathrm{O}(9: 1) \text { with } 3 \text { cycles of } 2 \mathrm{~h} \\
\text { and a full night in stirring in the dark } \\
\text { Fractionation of the active fraction was carried out } \\
\text { using a liquid/liquid extraction with methylene } \\
\text { chloride in proportion } \mathrm{CH}_{2} \mathrm{Cl}_{2} / \mathrm{H}_{2} \mathrm{O}(5: 5)\end{array}$ & $\begin{array}{l}\text { Essential oil yield: } 6.3 \mathrm{~mL} / \mathrm{kg} \text { of dry cones } \\
\text { Identification of } 16 \text { compounds, the three } \\
\text { major compounds being myrcene, } \\
\text { trans-caryophyllene, and } \alpha \text {-humulene }\end{array}$ & [10] \\
\hline Whole hop cones & $\begin{array}{l}\text { Essential oil } \\
\text { (monoterpenes and } \\
\text { sequiterpenes) }\end{array}$ & Steam distillation & Sequential elution at 8 distillation time & $\begin{array}{l}\text { Essential oil yield: } 83.2 \% \text { (the first hour), } \\
9.6 \% \text { (the second hour), and } 7.2 \% \text { (second } \\
\text { half of the distillation) } \\
\text { Chemical profile: Monoterpenes are the } \\
\text { first to be eluted and sequiterpenes were } \\
\text { later eluted }\end{array}$ & [42] \\
\hline Spent hops & $\begin{array}{c}\text { Flavonoids } \\
\text { (xanthohumol) }\end{array}$ & SLE & $\begin{array}{l}\text { Extraction with methylene chloride, acetone, ethyl } \\
\text { acetate, and methanol for } 24 \mathrm{~h} \text { on a rotary shaker and } \\
\text { LSR } 4: 1(\mathrm{~mL} / \mathrm{g})\end{array}$ & $\begin{array}{c}\text { Yield: } 92.95 \mathrm{~g} / \mathrm{kg} \text { (methanol); } 38.57 \mathrm{~g} / \mathrm{kg} \\
\text { (ethyl acetate); } 29.82 \mathrm{~g} / \mathrm{kg} \text { (acetone); } 26.01 \\
\mathrm{~g} / \mathrm{kg} \text { (methylene chloride) } \\
\text { Xanthohumol: } 3.51 \mathrm{~g} / \mathrm{kg} \text { (ethyl acetate); } \\
2.97 \mathrm{~g} / \mathrm{kg} \text { (acetone), } 2.94 \mathrm{~g} / \mathrm{kg} \text { (methanol); } \\
1.33 \mathrm{~g} / \mathrm{kg} \text { (methylene chloride) }\end{array}$ & [43] \\
\hline Hops & $\begin{array}{l}\text { Prenylflavonoids and } \\
\text { bitter acids } \\
\text { (prenylphloroglucinols) }\end{array}$ & Dynamic maceration & $\begin{array}{l}\text { Extraction with } \mathrm{MeOH}-\mathrm{HCOOH}(99: 1, v / v) \text {, at room } \\
\text { temperature for } 30 \text { min under magnetic stirring using } \\
\text { an LSR of } 20 \mathrm{~mL} / \mathrm{g}\end{array}$ & $\begin{array}{l}\approx 17.5 \mathrm{mg} / \mathrm{g} \text { bitter acids and } \approx 1.4 \mathrm{mg} / \mathrm{g} \\
\text { prenylflavonoids }\end{array}$ & [44] \\
\hline Hops & Polyphenols & SLE & $\begin{array}{c}\text { Extraction with DES based on glycerol and L-alanine } \\
\text { for } 150 \mathrm{~min} \text {, at } 50^{\circ} \mathrm{C} \text { in an oil bath. Optimal } \\
\text { conditions of extraction: } C_{\mathrm{DES}}=85 \%(w / w) \\
\mathrm{LSR}=59 \mathrm{~mL} / \mathrm{g} \text {, and } \mathrm{S}_{\mathrm{S}}=688 \mathrm{rpm}\end{array}$ & Yield: $118.97 \mathrm{mg}$ GAE/of dry mass & [23] \\
\hline Hop leaves & Polyphenols & UAE & $\begin{array}{c}\text { Extraction with methyl, ethyl, and isopropyl alcohol } \\
\text { at different concentrations }(40 \%, 70 \% \text {, and } 96-99.5 \% \\
(v / v)) \text { using a frequency of } 40 \mathrm{kHz} \text { for } 15,30 \text {, and } \\
60 \text { min at room temperature }\end{array}$ & $\begin{array}{l}\text { TPC: } 0.51-6.60 \mathrm{mg} \mathrm{GA} / \mathrm{g} \text { raw material } \\
\text { (collected in 2017) and } 0.02-6.22 \mathrm{GA} / \mathrm{g} \\
\text { raw material (collected in 2018) }\end{array}$ & [3] \\
\hline Hop extracts & $\begin{array}{l}\text { Essential oils ( } \beta \text {-myrcene } \\
\quad \text { and } \alpha \text {-humulene) }\end{array}$ & MAHD & $\begin{array}{c}335 \mathrm{~W} \text { microwave power for } 30 \text { min using an LSR of } \\
\text { 8:3 (using water as solvent) }\end{array}$ & $\begin{array}{c}\text { Yield: } 3.77 \% \text {; } \beta \text {-myrcene: } 77.36 \% \text {; } \\
\alpha \text {-humulene: } 9.47 \%\end{array}$ & [50] \\
\hline Hop flowers & $\begin{array}{l}\text { Acidic compounds ( } \alpha \\
\text { acids, iso } \alpha \text { acids, } \beta \text { acids) }\end{array}$ & $\begin{array}{l}\text { PLE with a Naviglio } \\
\text { Extractor }\end{array}$ & $\begin{array}{l}\text { Sample weight: } 21 \mathrm{~g} \text {; solvent: ethyl alcohol; static } \\
\text { phase: } 2 \text { min; dynamic phase: } 5 \text { cycles with } 12 \text { sec of } \\
\text { stop piston; total cycles: } 360(24 \mathrm{~h})\end{array}$ & $\begin{array}{c}\alpha \text { acids: } 50.2 \% \text {; iso } \alpha \text { acids: } 9.3 \% ; \beta \text { acids: } \\
16.3 \%\end{array}$ & [53] \\
\hline Hops (pellets) & $\begin{array}{l}\text { Isoxanthohumol and } \\
\text { xanthohumol }\end{array}$ & PHWE/PLE & $\begin{array}{l}\text { PHWE: } 1500 \mathrm{psi} \text { at } 150^{\circ} \mathrm{C} \text { and extraction time of } \\
30 \mathrm{~min}(5 \mathrm{~min} \text { by cycle }-6 \text { cycles- }) \\
\text { PLE: EtOH as a solvent, after using hexane at } 150{ }^{\circ} \mathrm{C} \\
\text { for } 20 \text { min each extraction }\end{array}$ & $\begin{array}{c}\text { PHWE: } 2.34 \mathrm{mg} / \mathrm{g} \text { of isoxanthohumol } \\
\text { and } 0.11 \mathrm{mg} / \mathrm{g} \text { of xanthohumol } \\
\text { PLE: } 5.15 \mathrm{mg} / \mathrm{g} \text { of isoxanthohumol and } \\
2.57 \mathrm{mg} / \mathrm{g} \text { of xanthohumol }\end{array}$ & [51] \\
\hline Hop and hop products & $\alpha$ - and $\beta$-acids & PSE & $\begin{array}{l}\text { PSE optimal conditions: number of cycles } 3(5 \mathrm{~min} \\
\text { each), static mode, } 80^{\circ} \mathrm{C}, 15 \mathrm{MPa} \text {, solvent: } \\
\text { methanol-diethylether }(1: 1) \text {, inert matrix: sea sand } \\
\text { (50 to } 70 \mu \mathrm{m}) \text {, solvent rinsing: } 20 \text { sec, nitrogen } \\
\text { blowdown: } 2 \mathrm{~min} \text {, amount of sample: } 1.5 \mathrm{~g} \text { of ground } \\
\text { hop cones or pellets or } 0.3 \mathrm{~g} \text { of hop extract }\end{array}$ & Yields between $96.8 \%$ and $102.7 \%$ & [52] \\
\hline
\end{tabular}


Table 1. Cont.

\begin{tabular}{|c|c|c|c|c|c|}
\hline Matrix & Target Compound & Method & Extraction Conditions & Outcomes & Reference \\
\hline Hop flowers & $\begin{array}{l}\text { Acidic compounds ( } \alpha \\
\text { acids, } \beta \text { acids) }\end{array}$ & SFE & $\begin{array}{c}\text { SFE-CO }{ }_{2} \text { (SFE-I) and SFE- } \mathrm{CO}_{2} \text { with ethanol (SFE-II): } \\
350 \text { bar at } 35^{\circ} \mathrm{C} \text {, a static period of } 10 \mathrm{~min} \text {, and a } \\
\text { dynamic phase of } 260 \mathrm{~min}\end{array}$ & $\begin{array}{l}\text { SFE-I: } 21.5 \% \alpha \text { acids; } 46.2 \% \beta \text { acids } \\
\text { SFE-II: } 28.3 \% \alpha \text { acids; } 37.5 \% \beta \text { acids }\end{array}$ & [53] \\
\hline $\begin{array}{l}\text { Hop pellets (Herkules and } \\
\text { Hallertau Magnum) }\end{array}$ & $\begin{array}{c}\text { Acidic compounds } \\
\text { ( } \alpha \text {-acids (cohumulone), } \\
\beta \text {-acids (colupulone)) }\end{array}$ & SFE & $\begin{array}{l}\text { SFE- } \mathrm{CO}_{2} \text { was carried out at a pressure of } 29 \mathrm{MPa} \text {, } \\
\qquad 50^{\circ} \mathrm{C} \text { during } 4 \mathrm{~h}\end{array}$ & $\begin{array}{c}\text { H. lupulus 'Herkules': } 55.2 \% \text { of } \alpha \text {-acids } \\
\text { (38.7\% of cohumulone); } 18.3 \% \text { of } \beta \text {-acids } \\
\text { (57.2\% colupulone) } \\
\text { H. lupulus 'Hallertau Magnum': } 46.9 \% \\
\text { of } \alpha \text {-acids ( } 24.9 \% \text { of cohumulone); } 22.9 \% \\
\text { of } \beta \text {-acids ( } 44.2 \% \text { colupulone) }\end{array}$ & [54] \\
\hline Spent hops & Xanthohumol & SFE & $\begin{array}{l}\text { SFE- } \mathrm{CO}_{2} \text { was carried out at a pressure of } 850 \text { bar at } 80 \\
{ }^{\circ} \mathrm{C}\end{array}$ & $1.23 \%$ of yield of xanthohumol & [55] \\
\hline
\end{tabular}




\section{Biological Activities of Hop Compounds}

As mentioned previously, hop contains several bioactive molecules that exhibit multiple therapeutic properties, such as (1) antioxidant, (2) antimicrobial, (3) antifungal, (4) antiviral, (5) anti-inflammatory, and (6) anticancer, inter alia $[5,12,53]$.

\subsection{Antioxidant Activity}

Several of the compounds identified in hops and hop products have been investigated for their antioxidant properties. The antioxidant potential of hop extracts depends on various factors including the type of assay used to determine the antioxidant activity, the extraction solvent, as well as the cultivar of hop [43,49,56]. For example, Kobus-Cisowska et al. [56] evaluated the antioxidant potential of hop cone extracts from three different cultivars (Magnum, Lubelski, and Marynka) measured by DPPH and ABTS methods. The aqueous extracts of the three cultivars presented the highest DPPH values; however, the ethanolic extracts exhibited a higher value of antioxidant activity by the ABTS assay.

Alonso-Esteban et al. [2] tested the antioxidant capacity of methanolic extract from hop seeds through different in vitro assays, namely the DPPH, reducing power, $\beta$-carotene bleaching inhibition, and thiobarbituric acid reactive substances (TBARS) formation inhibition. This extract had a greater inhibitory effect on the generation of TBARS from the ex vivo decomposition of certain lipid peroxidation products (with an $\mathrm{EC}_{50}$ value of $128 \mu \mathrm{g} / \mathrm{mL}$ ), but it exhibited the worst behavior for the $\beta$-carotene bleaching inhibition capacity (with an $\mathrm{EC}_{50}$ value of $1330 \mu \mathrm{g} / \mathrm{mL}$ ). The latter indicates that the hop extract is less active to neutralize the linoleic hydroperoxyl radicals formed in vitro from the oxidation of linoleic acid. The authors attributed the antioxidant potential mainly to the presence of (+)-catechin and (-)-epicatechin in hop seed extract.

In a previous study, Abram et al. [57] found that ethanolic extracts of hop cones presented up to ca.5-fold more DPPH activity compared to that obtained in the leaf extracts. On the contrary, the best activity measured by the ferric reducing antioxidant power (FRAP) trial was found in the leaf extracts. In another study, Gerhauser et al. reported that the xanthohumol present in the hops showed an antioxidant activity that was 8.9 and 2.9 times higher than the reference compound 6-hydroxy-2,5,7,8-tetramethylchroman-2-carboxylic acid (TROLOX) in scavenging hydroxyl and peroxyl radicals, respectively [58].

In a study carried out by Liu et al. [59], the hydroxyl radical scavenging activity of different hops fractions (hop bitter acids, isomerized hop bitter acids, and others) was evaluated. The results indicated that all the compounds showed antioxidant potential at different levels, of which the $\alpha$-acids were those that exhibited a lower $\mathrm{EC}_{50}$. Humulone, lupulone, and some terpenes (linalool, $\beta$-pinene and $\gamma$-terpinene, $\beta$-farnesene) from hop essential oils have also been reported for their antioxidant potential [12].

\subsection{Antimicrobial Activity}

Hops have traditionally been used in beer as a natural preservative because of their high content of bitter acids and polyphenols, which inhibit the growth of a broad spectrum of microorganisms. Pilna et al. [54] studied the antimicrobial potential of extracts of two hop varieties. All extracts showed antimicrobial activity against all pathogenic bacteria tested at minimum inhibitory concentrations (MICs) in the range of 8-512 $\mu \mathrm{g} / \mathrm{mL}$. Gram-positive strains (MICs 8-64 $\mu \mathrm{g} / \mathrm{mL}$ ) were more sensitive than Gram-negative strains (MICs $\geq 32 \mu \mathrm{g} / \mathrm{mL}$ ) and yeast (MIC $=512 \mu \mathrm{g} / \mathrm{mL}$ ). The authors identified $\alpha$ - and $\beta$-acids as the main substances involved in the inhibitory effects of hop extracts. Humulinic acid (derived from iso- $\alpha$-acids) has also been reported for their antimicrobial activity against Lactobacillus brevis [60].

Today, there is a global concern to find new active agents to combat microbial resistance to antibiotics [61]. In this sense, methicillin-resistant Staphylococcus aureus (MRSA) strains cause different pathologies that are difficult to treat due to their virulence, resistance to almost all useful antibiotics, as well as the formation of persistent biofilms [61]. Plant-derived natural compounds, 
characterized by the presence of a wide spectrum of active biomolecules, have been studied as potential antimicrobial agents that are useful to treat several diseases caused by multidrugresistant microorganisms. According to Bartmánska et al. [43], seven flavonoids, among them two natural ( $\alpha, \beta$-dihydroxanthohumol and 8-prenylnaringenin) flavonoids identified in spent hops extracts, showed remarkable antimicrobial activity against methicillin-sensitive (MSSA) and resistant Staphylococcus aureus (MRSA) strains. Lupulone, xanthohumol, and desmethylxanthohumol also exhibited strong antimicrobial activity against MRSA as well as the ability to inhibit biofilm formation [61]. Similar findings were also found by Bogdanova et al. [62], who reported that humulone, lupulone, and xanthohumol had strong antimicrobial and antibiofilm activity against MRSA strains. In this research, the authors indicated that lupulone exhibited the strongest effect, which was followed by xanthohumol. Ethanolic extracts of hops also exhibited an antimycobacterial effect on rifampin-sensitive and resistant strains of Mycobacterium tuberculosis [63].

Some authors have also demonstrated the antifungal activity of hop extracts. Bocquet et al. [10] tested crude extracts of different parts of hop (leaves, stems, rhizomes, and female cones) and the essential oil of hops against Zymoseptoria tritici. All extracts and essential oil showed antifungal activity, although only female cones and the essential oil exhibited a visible activity, observing a reduction of $85 \%$ and $100 \%$ in the growth of $\mathrm{Z}$. tritici at $1.25 \mathrm{~g} / \mathrm{L}$, respectively. The authors attributed the antifungal activity of hop cone extracts to the presence of desmethylxanthohumol and co-humulone and concluded that the combination of hops essential oil with synthetic fungicides could be an appropriate strategy to reduce the dose of conventional fungicides in crop protection. Similarly, Alonso-Esteban et al. [2] also reported the antifungal activity of hop seed extract. The results indicated that this extract had a remarkable antifungal effect, which was even better than the positive control, against fungi of the genus Penicillium.

\subsection{Effects on Specific Diseases}

\subsubsection{Anti-Inflammatory Activity}

Inflammation is a biological response of the organism to injury or infection [12]. However, according to the authors, an excessive inflammatory reaction is associated with certain diseases such as cancer or ischemic heart disease, among others. Bitter acids and polyphenolic compounds from hops have been identified as promising molecules to inhibit inflammatory processes. Both molecules act on the nuclear factor kappa B (NF-kB) that is involved in the expression of pro-inflammatory genes such as tumor necrosis factor alpha (TNF- $\alpha$ ), inducible nitric oxide synthase (iNOS), kinases, cyclooxygenases 1 and 2 (COX-1 and COX-2), and an amount interleukins [12,64]. Several in vitro and in vivo studies evidenced that the anti-inflammatory effects of hops are primarily attributed to humulone, xanthohumol, and 8-prenylnaringenin [12,64]. For instance, Lee et al. [65] reported that the topical application of humulone inhibited 12-O-tetradecanoylphorbol-13 acetate (TPA)-induced COX-2 expression through the regulation of nuclear factor-kB. Humulone also reduces the expression of various kinases related to the inflammatory response [66]. Xanthohumol and 8-prenylnaringenin also showed a strong anti-inflammatory effect via the inactivation of NF-kc in microglial cell lines [67]. It has also been studied that the isoxanthohumol reduced inflammatory factors including tumor necrosis factor alpha (TNF- $\alpha$ ) and nuclear factor kappa B in human aortic smooth muscle cells and human umbilical vein endothelial cells [68]. In both animal models and human intervention trials, isohumulones have been effective in the treatment of inflammatory arthritis [69].

\subsubsection{Cancer-Related Activities}

Cancer, an important causes of death in the $21^{\text {st }}$ century, supposes for the health systems an important economic impact, due to the high cost of its treatment [12]. For this reason, it is necessary to develop new substances with anticancer potential that can prevent, stop, or reverse the disease progression, which is the reason why these substances have been the focus of a large number of scientific 
studies [12]. In this context, it has been reported that some of the bioactive compounds present in hops have anticancer properties. For instance, xanthohumol has been identified as a new agent for the treatment of different types of cancer [12,64]. Yong et al. [11] demonstrated that xanthohumol had an apoptotic effect on the human alveolar adenocarcinoma cell line in a dose- and time-dependent manner. Recently, Roehrer et al. [13] evaluated the antiproliferative effect of xanthohumol, xanthohumol C, and crude hop extract on human breast cancer cells. According to the authors, after 2 days of incubation, xanthohumol $\mathrm{C}$ presented the strongest growth inhibition with an $\mathrm{IC}_{50}$ of $4.18 \mu \mathrm{M}$, in comparison with crude hop extract $(8.84 \mu \mathrm{M})$ and xanthohumol $(12.25 \mu \mathrm{M})$. Lupulone, a $\beta$-acid present in hop extracts, displayed anticancer activity on prostate cancer cells via the induction of caspase 8-dependent cell death [70].

\subsubsection{Other Biological Activities}

Other bioactivities attributed to hop components include neuroprotective, antidiabetic, and cardioprotective effects. Xanthohumol promoted neuronal recovery in rats with intracerebral hemorrhage [71], and it also showed a protective effect on the brain damage induced by aging [72]. This compound also has the ability to inhibit adipogenesis so it can be used in the prevention of obesity. In a study in mice fed with a high-fat diet, the supplementation with $2 \%$ or $5 \%$ hop extract reduced the increase in body and adipose tissue weight and improved the glucose intolerance [73]. A diet rich in xanthohumol and 8-prenylnaringenin improves metabolic disorders related to type-2 diabetes by modulation of the glucose and lipid pathways [74].

Table 2 summarizes several biological activities of different biocompounds extracted from hop and the main results found.

Table 2. Biological activities of compounds extracted from hops.

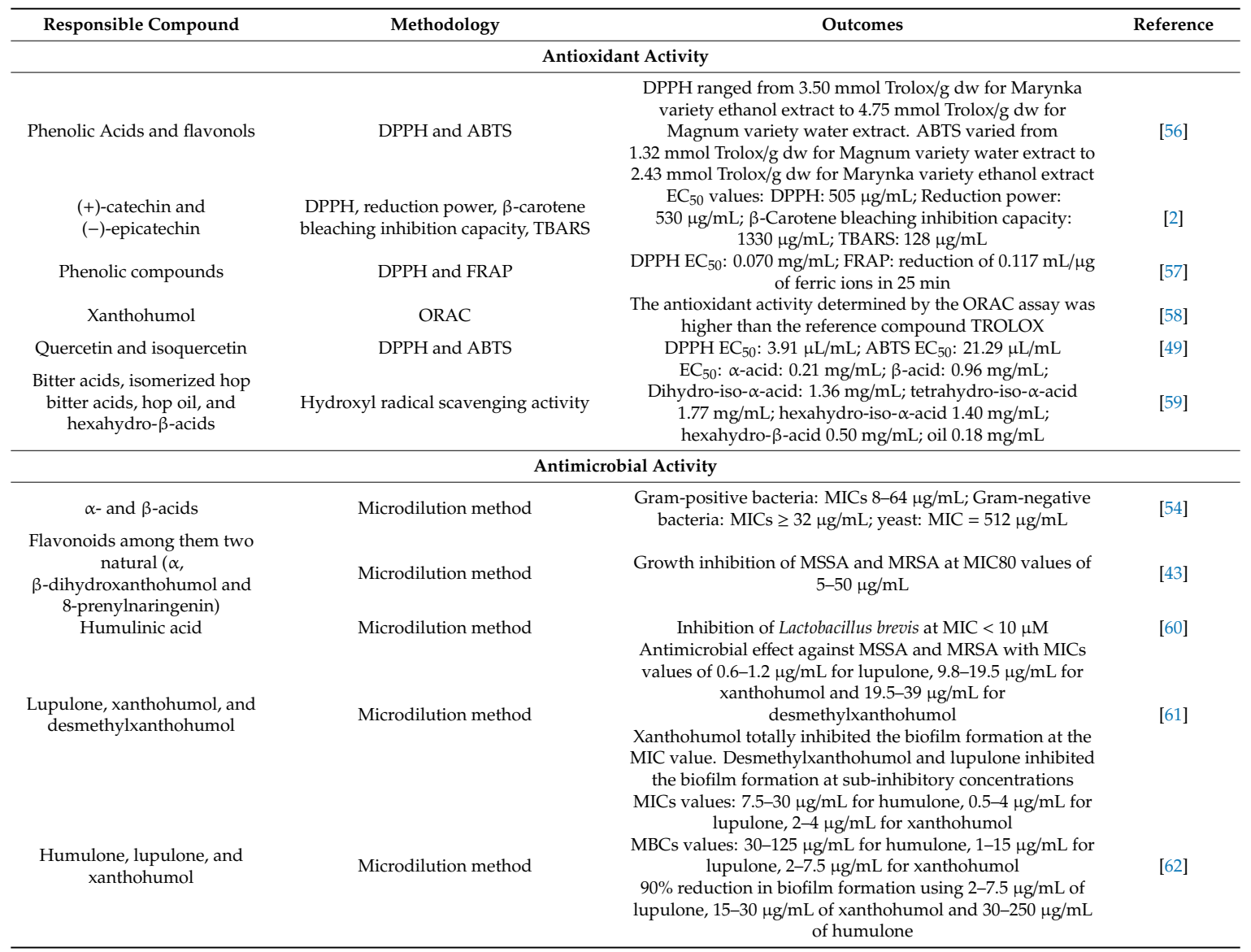


Table 2. Cont.

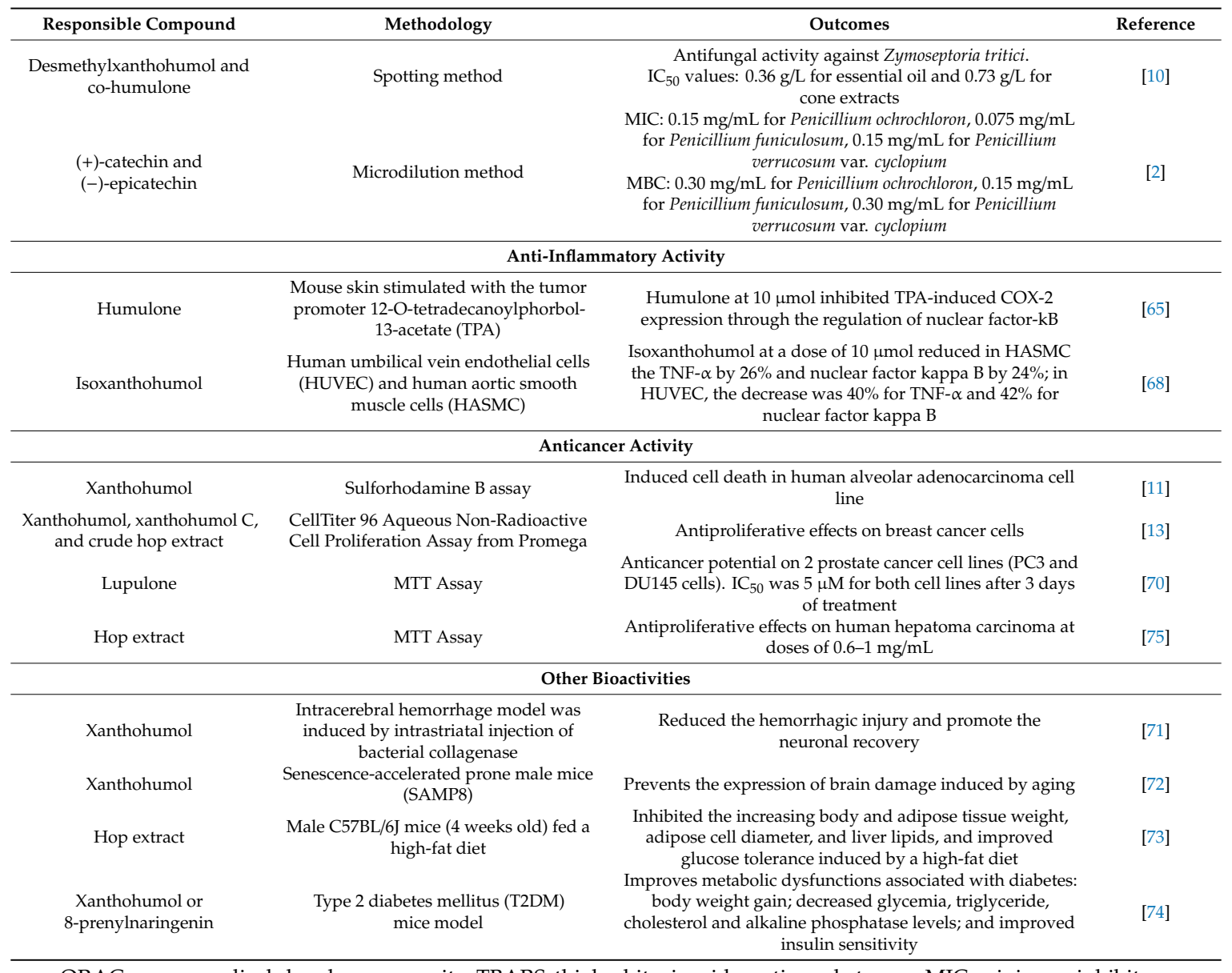

ORAC: oxygen radical absorbance capacity; TBARS: thiobarbituric acid reactive substances; MIC: minimum inhibitory concentration; MBC: minimum bactericidal concentration; MSSA: methicillin sensitive strains Staphylococcus; MRSA: methicillin resistant strains Staphylococcus; TPA: 12-O-tetradecanoylphorbol-13-acetate; MTT: 3-(4,5-dimethy lthiazol-2-yl)-2,5-diphenyltetrazolium bromide.

\section{Current Applications of Functional Molecules from Hop}

Taking into account the properties of the hop extracts, in the last years, they have been used as preservative agents in different food products. In the case of fresh meat and meat products, plant extracts prevent their oxidative and microbial deterioration, extending their shelf-life and safety as well as conferring functional properties [76-78]. For example, Kramer et al. [18] studied the antimicrobial effect in vitro of several hop extracts against L. monocytogenes, Staphylococcus aureus, Salmonella enterica, and Escherichia coli in a model meat marinade and on marinated pork tenderloins. The results obtained by these authors demonstrated that the Gram-positive bacteria were highly inhibited by hop extracts due to its content in $\beta$-acid, but in the case of extracts containing $\alpha$-acid, the inhibition was lower; in contrast, Gram-negative bacteria exhibited a high resistance against all evaluated hop extracts.

In another work, Villalobos-Delgado et al. [79] evaluated the effect of the incorporation of hop infusion or powder in raw and cooked lamb patties, over the oxidative stability of lipids, proteins, and/or color under two scenarios: refrigerated or frozen conditions, as well as in their sensory acceptability. These authors concluded that the use of hop powder showed higher antioxidant activity than hop infusion in lamb patties. Moreover, the lipid and protein oxidation of cooked patties under refrigerated conditions was reduced. However, the sensorial acceptance by the consumers decreased due to changes in flavor when hop powder was added.

Hop extracts find also application as natural ingredients to extend the shelf life of bread due to their antifungal properties. For instance, Nionelli et al. [19] formulated wheat bread with hop 
extracts and assessed their effects on its shelf life, as well as on its rheological and sensory features. They reported that the hop extract exhibited antifungal properties against Aspergillus parasiticus, Penicillium carneum, Penicillium polonicum, Penicillium paneum, Penicillium chermesinum, Aspergillus niger, and Penicillium roqueforti. Moreover, these authors isolated lactic acid bacteria from hops and selected three for sourdough fermentation for bread making with hop extracts. The authors concluded that the addition of hop extracts increased the antioxidant activity and the concentration of phenols. Moreover, the use of hop-sourdough with or without the incorporation of hop extract to elaborate bread delayed the growth of fungi until 14 days, extending its shelf life. The rheological and sensory properties were not affected.

In cosmetics, hops are used in bath lotions, among others [80]. Vogt et al. [17] used supercritical $\mathrm{CO}_{2}$ extracts of hop cones to formulate shower gels, and the results obtained showed that their addition enhanced their skin-conditioning properties due to their content in bioactive ingredients. Moreover, the formulations containing the extract of hop cones present compounds to treat oil and dandruff in hair. The use of hop extract in hair cosmetics is supported by its antifungal and antiseborrheic properties that decrease its brittleness, nourish it, give it shine, increase its strength, and prevent its loss [17].

\section{Conclusions}

Traditionally, hops have been used in brewing, but recent studies have revealed their wealth in bioactive molecules with a huge range of therapeutic properties. This has encouraged intense research in the development of a sustainable process that uses eco-friendly solvents combined with intensification technologies that guarantee high yields and extracts with high quality from hops. In fact, in this review, several works based on these technologies demonstrate their suitability to recover extracts that are biologically active. A myriad of properties related to the hop extracts have been evaluated, among them antibacterial, antifungal, cardioprotective, antioxidant, anti-inflammatory, anticarcinogenic, and antiviral. Therefore, hops are shaping up as an excellent and alternative source of bioactive compounds with potential great acceptability by the consumers that increasingly demand natural ingredients with healthy properties. Moreover, the extracts from hops find applications in the alimentary, cosmetic, nutraceutical, and pharmaceutical sector, opening new alternatives in the formulation of different commodities beyond their conventional uses. However, due to the huge variety of biomolecules present in the hop extracts, it is necessary to investigate their interaction with other components of the matrix where they are incorporated, as well as their bioavailability when are ingested as part of a food or used at a topical level when being applied as part of a skin or hair formulation.

Author Contributions: Conceptualization, B.G.; writing—original draft preparation, G.A., P.G., B.G.; writingreview and editing, P.G., G.A., B.G., P.E.S.M., J.M.L. All authors have read and agreed to the published version of the manuscript.

Funding: Thanks to GAIN (Axencia Galega de Innovación) for supporting this research (grant number IN607A2019/01).

Acknowledgments: Gonzalo Astray thanks to the University of Vigo for his contract supported by "Programa de retención de talento investigador da Universidade de Vigo para o 2018" budget application 0000 131H TAL 641. B.G. acknowledges postdoctoral fellowship support from the Ministry of Economy and Competitiveness (MINECO, Spain) "Ramón y Cajal" program (Grant reference RYC2018-026177-I). Paulo E.S. Munekata acknowledges postdoctoral fellowship support from the Ministry of Economy and Competitiveness (MINECO, Spain) "Juan de la Cierva" program (FJCI-2016-29486). Jose M. Lorenzo is member of the HealthyMeat network, funded by CYTED (ref. 119RT0568).

Conflicts of Interest: The authors declare no conflict of interest. 


\section{References}

1. Krottenthaler, M. Hops. In Handbook of Brewing: Processes, Technology, Markets; Eßlinger, H.M., Ed.; WILEY-VCH: Weinheim, Germany, 2009; pp. 85-104.

2. Alonso-Esteban, J.I.; Pinela, J.; Barros, L.; Ćirić, A.; Soković, M.; Calhelha, R.C.; Torija-Isasa, E.; de Cortes Sánchez-Mata, M.; Ferreira, I.C.F.R. Phenolic composition and antioxidant, antimicrobial and cytotoxic properties of hop (Humulus lupulus L.) Seeds. Ind. Crops Prod. 2019, 134, 154-159. [CrossRef]

3. Muzykiewicz, A.; Nowak, A.; Zielonka-Brzezicka, J.; Florkowska, K.; Duchnik, W.; Klimowicz, A. Comparison of antioxidant activity of extracts of hop leaves harvested in different years. Herba Pol. 2019, 65, 1-9. [CrossRef]

4. Moir, M. Hops-A millennium review. J. Am. Soc. Brew. Chem. 2000, 58, 131-146. [CrossRef]

5. Hrnčič, M.K.; Španinger, E.; Košir, I.J.; Knez, Ž.; Bren, U. Hop compounds: Extraction techniques, chemical analyses, antioxidative, antimicrobial, and anticarcinogenic effects. Nutrients 2019, 11, 257. [CrossRef] [PubMed]

6. European Commission. Hop Report for the Harvest Year 2018; European Commission: Brussels, Belgium, 2018.

7. Tardío, J.; De Cortes Sánchez-Mata, M.; Morales, R.; Molina, M.; García-Herrera, P.; Morales, P.; Díez-Marqués, C.; Fernández-Ruiz, V.; Cámara, M.; Pardo-De-Santayana, M.; et al. Ethnobotanical and food composition monographs of selected mediterranean wild edible plants. In Mediterranean Wild Edible Plants: Ethnobotany and Food Composition Tables; De Cortes Sánchez-Mata, M., Tardío, J., Eds.; Springer: New York, NY, USA, 2016; pp. 273-470.

8. Lorenzo, J.M.; Mousavi Khaneghah, A.; Gavahian, M.; Marszałek, K.; Eş, I.; Munekata, P.E.S.; Ferreira, I.C.F.R.; Barba, F.J. Understanding the potential benefits of thyme and its derived products for food industry and consumer health: From extraction of value-added compounds to the evaluation of bioaccessibility, bioavailability, anti-inflammatory, and antimicrobial activities. Crit. Rev. Food Sci. Nutr. 2019, 59, 2879-2895. [CrossRef]

9. Zanoli, P.; Zavatti, M. Pharmacognostic and pharmacological profile of Humulus lupulus L. J. Ethnopharmacol. 2008, 116, 383-396. [CrossRef]

10. Bocquet, L.; Rivière, C.; Dermont, C.; Samaillie, J.; Hilbert, J.-L.; Halama, P.; Siah, A.; Sahpaz, S. Antifungal activity of hop extracts and compounds against the wheat pathogen Zymoseptoria tritici. Ind. Crops Prod. 2018, 122, 290-297. [CrossRef]

11. Yong, W.K.; Ho, Y.F.; Malek, S.N.A. Xanthohumol induces apoptosis and S phase cell cycle arrest in A549 non-small cell lung cancer cells. Pharmacogn. Mag. 2015, 11, S275-S283.

12. Karabín, M.; Hudcová, T.; Jelínek, L.; Dostálek, P. Biologically Active Compounds from Hops and Prospects for Their Use. Compr. Rev. Food Sci. Food Saf. 2016, 15, 542-567. [CrossRef]

13. Roehrer, S.; Stork, V.; Ludwig, C.; Minceva, M.; Behr, J. Analyzing bioactive effects of the minor hop compound xanthohumol C on human breast cancer cells using quantitative proteomics. PLoS ONE 2019, 14, e0213469. [CrossRef]

14. Steenackers, B.; De Cooman, L.; De Vos, D. Chemical transformations of characteristic hop secondary metabolites in relation to beer properties and the brewing process: A review. Food Chem. 2015, 172, 742-756. [CrossRef] [PubMed]

15. Sanz, V.; Torres, M.D.; López Vilariño, J.M.; Domínguez, H. What is new on the hop extraction? Trends Food Sci. Technol. 2019, 93, 12-22. [CrossRef]

16. Almaguer, C.; Schönberger, C.; Gastl, M.; Arendt, E.K.; Becker, T. Humulus lupulus-A story that begs to be told. A review. J. Inst. Brew. 2014, 120, 289-314. [CrossRef]

17. Vogt, O.; Sikora, E.; Ogonowski, J. The effect of selected supercritical $\mathrm{CO}_{2}$ plant extract addition on user properties of shower gels. Polish J. Chem. Technol. 2014, 16, 51-54. [CrossRef]

18. Kramer, B.; Thielmann, J.; Hickisch, A.; Muranyi, P.; Wunderlich, J.; Hauser, C. Antimicrobial activity of hop extracts against foodborne pathogens for meat applications. J. Appl. Microbiol. 2015, 118, 648-657. [CrossRef] [PubMed]

19. Nionelli, L.; Pontonio, E.; Gobbetti, M.; Rizzello, C.G. Use of hop extract as antifungal ingredient for bread making and selection of autochthonous resistant starters for sourdough fermentation. Int. J. Food Microbiol. 2018, 266, 173-182. [CrossRef] [PubMed]

20. Jelínek, L.; Karabín, M.; Kotlíková, B.; Hudcová, T.; Dostálek, P. Application of a hop by-product in brewing: Reduction in the level of haze-active prolamines and improved antioxidant properties of the beer. J. Inst. Brew. 2014, 120, 99-104. [CrossRef] 
21. Marriott, R.J. Greener chemistry preparation of traditional: Lavour extracts and molecules. Agro Food Ind. Hi-Tech 2010, 21, 46-48.

22. Barba, F.J.; Putnik, P.; Bursać Kovačević, D.; Poojary, M.M.; Roohinejad, S.; Lorenzo, J.M.; Koubaa, M. Impact of conventional and non-conventional processing on prickly pear (Opuntia spp.) and their derived products: From preservation of beverages to valorization of by-products. Trends Food Sci. Technol. 2017, 67, $260-270$. [CrossRef]

23. Lakka, A.; Karageorgou, I.; Kaltsa, O.; Batra, G.; Bozinou, E.; Lalas, S.; Makris, D. Polyphenol Extraction from Humulus lupulus (Hop) Using a Neoteric Glycerol/L-Alanine Deep Eutectic Solvent: Optimisation, Kinetics and the E ect of Ultrasound-Assisted Pretreatment. AgriEngineering 2019, 1, 30. [CrossRef]

24. Putnik, P.; Lorenzo, J.; Barba, F.; Roohinejad, S.; Režek Jambrak, A.; Granato, D.; Montesano, D.; Bursać Kovačević, D. Novel food processing and extraction technologies of high-added value compounds from plant materials. Foods 2018, 7, 106. [CrossRef] [PubMed]

25. Bursać Kovačević, D.; Maras, M.; Barba, F.J.; Granato, D.; Roohinejad, S.; Mallikarjunan, K.; Montesano, D.; Lorenzo, J.M.; Putnik, P. Innovative technologies for the recovery of phytochemicals from Stevia rebaudiana Bertoni leaves: A review. Food Chem. 2018, 268, 513-521. [CrossRef] [PubMed]

26. Chemat, F.; Abert Vian, M.; Fabiano-Tixier, A.-S.; Nutrizio, M.; Režek Jambrak, A.; Munekata, P.E.S.; Lorenzo, J.M.; Barba, F.J.; Binello, A.; Cravotto, G. A review of sustainable and intensified techniques for extraction of food and natural products. Green Chem. 2020, 22, 2325-2353. [CrossRef]

27. Gullón, P.; Gullón, B.; Romaní, A.; Rocchetti, G.; Lorenzo, J.M. Smart advanced solvents for bioactive compounds recovery from agri-food by-products: A review. Trends Food Sci. Technol. 2020, 101, $182-197$. [CrossRef]

28. Gullón, B.; Lú-Chau, T.A.; Moreira, M.T.; Lema, J.M.; Eibes, G. Rutin: A review on extraction, identification and purification methods, biological activities and approaches to enhance its bioavailability. Trends Food Sci. Technol. 2017, 67, 220-235. [CrossRef]

29. Stevens, R. The Chemistry of Hop Constituents. Chem. Rev. 1967, 67, 19-71. [CrossRef]

30. Verzele, M. 100 years of hop chemistry and its relevance to brewing. J. Inst. Brew. 1986, 92, 32-48. [CrossRef]

31. Palamand, S.R.; Aldenhoff, J.M. Bitter tasting compounds of beer. Chemistry and taste properties of some hop resin compounds. J. Agric. Food Chem. 1973, 21, 535-543. [CrossRef]

32. Hough, J.S.; Briggs, D.E.; Stevens, R.; Young, T.W. Malting and Brewing Science. Volume II Hopped Wort and Beer; Springer Science + Business Media: New York, NY, USA, 1982.

33. Roberts, T.R.; Wilson, R.J.H. Hops. In Handbook of Brewing; Priest, F.G., Stewart, G.G., Eds.; Taylor \& Francis: Boca Raton, FL, USA, 2006; pp. 177-280.

34. Sharpe, F.R.; Laws, D.R.J. The essential oil of hops a review. J. Inst. Brew. 1981, 87, 96-107. [CrossRef]

35. Jahnsen, V.J. Complexity of Hop Oil. Nature 1962, 196, 474-475. [CrossRef]

36. Biendl, M. Hops and Health. Tech. Q. Master Brew. Assoc. Am. 2009, 46, 1-7. [CrossRef]

37. Taniguchi, Y.; Taniguchi, H.; Yamada, M.; Matsukura, Y.; Koizumi, H.; Furihata, K.; Shindo, K. Analysis of the components of hard resin in hops (Humulus lupulus L.) and structural elucidation of their transformation products formed during the brewing process. J. Agric. Food Chem. 2014, 62, 11602-11612. [CrossRef] [PubMed]

38. Biendl, M.; Engelhard, B.; Forster, A.; Gahr, A.; Lutz, A.; Mitter, W.; Schmidt, R.; Schönberger, C. Hops: Their Cultivation, Composition and Usage; Fachverlag Hans Carl: Nürnberg, Germany, 2014.

39. Spreng, S.; Hofmann, T. Activity-Guided Identification of in Vitro Antioxidants in Beer. J. Agric. Food Chem. 2018, 66, 720-731. [CrossRef] [PubMed]

40. Gresser, A. Properties and Quality. In Handbook of Brewing: Processes, Technology, Markets; Eßlinger, H.M., Ed.; WILEY-VCH: Weinheim, Germany, 2009; pp. 359-397. ISBN 9783527316748.

41. Alirezalu, K.; Pateiro, M.; Yaghoubi, M.; Alirezalu, A.; Peighambardoust, S.H.; Lorenzo, J.M. Phytochemical constituents, advanced extraction technologies and techno-functional properties of selected Mediterranean plants for use in meat products. A comprehensive review. Trends Food Sci. Technol. 2020, 100, $292-306$. [CrossRef]

42. Jeliazkova, E.; Zheljazkov, V.D.; Kačániova, M.; Astatkie, T.; Tekwani, B.L. Sequential elution of essential oil constituents during steam distillation of hops (Humulus lupulus L.) and influence on oil yield and antimicrobial activity. J. Oleo Sci. 2018, 67, 871-883. [CrossRef] 
43. Bartmańska, A.; Wałecka-Zacharska, E.; Tronina, T.; Popłoński, J.; Sordon, S.; Brzezowska, E.; Bania, J.; Huszcza, E. Antimicrobial properties of spent hops extracts, flavonoids isolated therefrom, and their derivatives. Molecules 2018, 23, 2059. [CrossRef] [PubMed]

44. Prencipe, F.P.; Brighenti, V.; Rodolfi, M.; Mongelli, A.; dall'Asta, C.; Ganino, T.; Bruni, R.; Pellati, F. Development of a new high-performance liquid chromatography method with diode array and electrospray ionization-mass spectrometry detection for the metabolite fingerprinting of bioactive compounds in Humulus lupulus L. J. Chromatogr. A 2014, 1349, 50-59. [CrossRef]

45. Vilkhu, K.; Mawson, R.; Simons, L.; Bates, D. Applications and opportunities for ultrasound assisted extraction in the food industry-A review. Innov. Food Sci. Emerg. Technol. 2008, 9, 161-169. [CrossRef]

46. Tiwari, B.K. Ultrasound: A clean, green extraction technology. TrAC Trends Anal. Chem. 2015, 71, 100-109. [CrossRef]

47. Martínez-Patiño, J.C.; Gullón, B.; Romero, I.; Ruiz, E.; Brnčić, M.; Žlabur, J.Š.; Castro, E. Optimization of ultrasound-assisted extraction of biomass from olive trees using response surface methodology. Ultrason. Sonochem. 2019, 51, 487-495. [CrossRef]

48. Gullón, B.; Gagaoua, M.; Barba, F.J.; Gullón, P.; Zhang, W.; Lorenzo, J.M. Seaweeds as promising resource of bioactive compounds: Overview of novel extraction strategies and design of tailored meat products. Trends Food Sci. Technol. 2020, 100, 1-18. [CrossRef]

49. Almeida, A.D.R.; Maciel, M.V.D.O.B.; Machado, M.H.; Bazzo, G.C.; de Armas, R.D.; Vitorino, V.B.; Vitali, L.; Block, J.M.; Barreto, P.L.M. Bioactive compounds and antioxidant activities of Brazilian hop (Humulus lupulus L.) extracts. Int. J. Food Sci. Technol. 2020, 55, 340-347. [CrossRef]

50. Tyśkiewicz, K.; Gieysztor, R.; Konkol, M.; Szałas, J.; Rój, E. Essential oils from Humulus lupulus scCO 2 extract by hydrodistillation and microwave-assisted hydrodistillation. Molecules 2018, 23, 2866. [CrossRef] [PubMed]

51. Gil-Ramírez, A.; Mendiola, J.A.; Arranz, E.; Ruíz-Rodríguez, A.; Reglero, G.; Ibáñez, E.; Marín, F.R. Highly isoxanthohumol enriched hop extract obtained by pressurized hot water extraction (PHWE). Chemical and functional characterization. Innov. Food Sci. Emerg. Technol. 2012, 16, 54-60. [CrossRef]

52. Čulík, J.; Jurková, M.; Horák, T.; Čejka, P.; Kellner, V.; Dvořák, J.; Karásek, P.; Roth, M. Extraction of bitter acids from hops and hop products using Pressurized Solvent Extraction (PSE). J. Inst. Brew. 2009, 115, 220-225. [CrossRef]

53. Formato, A.; Gallo, M.; Ianniello, D.; Montesano, D.; Naviglio, D. Supercritical fluid extraction of $\alpha$ - and $\beta$-acids from hops compared to cyclically pressurized solid-liquid extraction. J. Supercrit. Fluids 2013, 84, 113-120. [CrossRef]

54. Pilna, J.; Vlkova, E.; Krofta, K.; Nesvadba, V.; Rada, V.; Kokoska, L. In vitro growth-inhibitory effect of ethanol GRAS plant and supercritical $\mathrm{CO}_{2}$ hop extracts on planktonic cultures of oral pathogenic microorganisms. Fitoterapia 2015, 105, 260-268. [CrossRef]

55. Jackowski, J.; Hurej, M.; Rój, E.; Popłoński, J.; Kośny, L.; Huszcza, E. Antifeedant activity of xanthohumol and supercritical carbon dioxide extract of spent hops against stored product pests. Bull. Entomol. Res. 2015, 105, 456-461. [CrossRef]

56. Kobus-Cisowska, J.; Szymanowska-Powałowska, D.; Szczepaniak, O.; Kmiecik, D.; Przeor, M.; Gramza-Michałowska, A.; Cielecka-Piontek, J.; Smuga-Kogut, M.; Szulc, P. Composition and in vitro effects of cultivars of humulus lupulus L. Hops on cholinesterase activity and microbial growth. Nutrients 2019, 11, 1377. [CrossRef]

57. Abram, V.; Čeh, B.; Vidmar, M.; Hercezi, M.; Lazić, N.; Bucik, V.; Možina, S.S.; Košir, I.J.; Kač, M.; Demšar, L.; et al. A comparison of antioxidant and antimicrobial activity between hop leaves and hop cones. Ind. Crops Prod. 2015, 64, 124-134. [CrossRef]

58. Gerhauser, C.; Alt, A.; Heiss, E.; Gamal-Eldeen, A.; Klimo, K.; Knauft, J.; Neumann, I.; Scherf, H.-R.; Frank, N.; Bartsch, H.; et al. Cancer chemopreventive activity of xanthohumol, a natural product derived from hop. Mol. Cancer Ther. 2002, 1, 959-969. [PubMed]

59. Liu, Y.; Gu, X.-H.; Tang, J.; Liu, K. Antioxidant activities of hops (Humulus lupulus) and their products. J. Am. Soc. Brew. Chem. 2007, 65, 116-121. [CrossRef]

60. Schurr, B.C.; Hahne, H.; Kuster, B.; Behr, J.; Vogel, R.F. Molecular mechanisms behind the antimicrobial activity of hop iso- $\alpha$-acids in Lactobacillus brevis. Food Microbiol. 2015, 46, 553-563. [CrossRef] [PubMed] 
61. Bocquet, L.; Sahpaz, S.; Bonneau, N.; Beaufay, C.; Mahieux, S.; Samaillie, J.; Roumy, V.; Jacquin, J.; Bordage, S.; Hennebelle, T.; et al. Phenolic compounds from humulus lupulus as natural antimicrobial products: New weapons in the fight against methicillin resistant staphylococcus aureus, leishmania mexicana and trypanosoma brucei strains. Molecules 2019, 24, 1024. [CrossRef] [PubMed]

62. Bogdanova, K.; Röderova, M.; Kolar, M.; Langova, K.; Dusek, M.; Jost, P.; Kubelkova, K.; Bostik, P.; Olsovska, J. Antibiofilm activity of bioactive hop compounds humulone, lupulone and xanthohumol toward susceptible and resistant staphylococci. Res. Microbiol. 2018, 169, 127-134. [CrossRef]

63. Esmi Serkani, J.; Nasr Isfahani, B.; Safaei, H.G.; Kasra Kermanshahi, R.; Asghari, G. Evaluation of the effect of humulus lupulus alcoholic extract on rifampin-sensitive and resistant isolates of mycobacterium tuberculosis. Res. Pharm. Sci. 2012, 7, 235-242.

64. Bocquet, L.; Sahpaz, S.; Hilbert, J.L.; Rambaud, C.; Rivière, C. Humulus lupulus L., a very popular beer ingredient and medicinal plant: Overview of its phytochemistry, its bioactivity, and its biotechnology. Phytochem. Rev. 2018, 17, 1047-1090. [CrossRef]

65. Lee, J.-C.; Kundu, J.K.; Hwang, D.-M.; Na, H.-K.; Surh, Y.-J. Humulone inhibits phorbol ester-induced COX-2 expression in mouse skin by blocking activation of NF- $\mathrm{kB}$ and AP-1: I $\mathrm{kB}$ kinase and c-Jun-N-terminal kinase as respective potential upstream targets. Carcinogenesis 2007, 28, 1491-1498. [CrossRef]

66. Van Cleemput, M.; Cattoor, K.; De Bosscher, K.; Haegeman, G.; De Keukeleire, D.; Heyerick, A. Hop (Humulus lupulus)-derived bitter acids as multipotent bioactive compounds. J. Nat. Prod. 2009, 72, 1220-1230. [CrossRef]

67. Bartmańska, A.; Tronina, T.; Popłoński, J.; Huszcza, E. Biotransformations of prenylated hop flavonoids for drug discovery and production. Curr. Drug Metab. 2013, 14, 1083-1097. [CrossRef]

68. Negrão, R.; Duarte, D.; Costa, R.; Soares, R. Isoxanthohumol modulates angiogenesis and inflammation via vascular endothelial growth factor receptor, tumor necrosis factor alpha and nuclear factor kappa $B$ pathways. BioFactors 2013, 39, 608-622. [CrossRef] [PubMed]

69. Bland, J.S.; Minich, D.; Lerman, R.; Darland, G.; Lamb, J.; Tripp, M.; Grayson, N. Isohumulones from hops (Humulus lupulus) and their potential role in medical nutrition therapy. PharmaNutrition 2015, 3, 46-52. [CrossRef]

70. Mouratidis, P.X.E.; Colston, K.W.; Tucknott, M.L.; Tyrrell, E.; Pirianov, G. An investigation into the anticancer effects and mechanism of action of hop $\beta$-acid lupulone and its natural and synthetic derivatives in prostate cancer cells. Nutr. Cancer 2013, 65, 1086-1092. [CrossRef] [PubMed]

71. Wang, Y.; Zhang, Y.; Ming, W.; Jin, X.; Zhai, K.; Liu, B.; Bai, H.; Liu, X. Xanthohumol promotes neuronal and behavioral recovery by suppressing inflammatory response and apoptosis in a rat model of intracerebral hemorrhage. Int. J. Clin. Exp. Med. 2017, 10, 7843-7850.

72. Rancán, L.; Paredes, S.D.; García, I.; Muñoz, P.; García, C.; López de Hontanar, G.; de la Fuente, M.; Vara, E.; Tresguerres, J.A.F. Protective effect of xanthohumol against age-related brain damage. J. Nutr. Biochem. 2017, 49, 133-140. [CrossRef] [PubMed]

73. Sumiyoshi, M.; Kimura, Y. Hop (Humulus lupulus L.) extract inhibits obesity in mice fed a high-fat diet over the long term. Br. J. Nutr. 2013, 109, 162-172. [CrossRef]

74. Costa, R.; Rodrigues, I.; Guardão, L.; Rocha-Rodrigues, S.; Silva, C.; Magalhães, J.; Ferreira-de-Almeida, M.; Negrão, R.; Soares, R. Xanthohumol and 8-prenylnaringenin ameliorate diabetic-related metabolic dysfunctions in mice. J. Nutr. Biochem. 2017, 45, 39-47. [CrossRef]

75. Cömert Önder, F.; Ay, M.; Aydoğan Türkoğlu, S.; Tura Köçkar, F.; Çelik, A. Antiproliferative activity of Humulus lupulus extracts on human hepatoma (Hep3B), colon (HT-29) cancer cells and proteases, tyrosinase, $\beta$-lactamase enzyme inhibition studies. J. Enzyme Inhib. Med. Chem. 2016, 31, 90-98. [CrossRef]

76. Nikmaram, N.; Budaraju, S.; Barba, F.J.; Lorenzo, J.M.; Cox, R.B.; Mallikarjunan, K.; Roohinejad, S. Application of plant extracts to improve the shelf-life, nutritional and health-related properties of ready-to-eat meat products. Meat Sci. 2018, 145, 245-255. [CrossRef]

77. Fernandes, R.P.P.; Trindade, M.A.; Lorenzo, J.M.; de Melo, M.P. Assessment of the stability of sheep sausages with the addition of different concentrations of Origanum vulgare extract during storage. Meat Sci. 2018, 137, 244-257. [CrossRef]

78. Domínguez, R.; Pateiro, M.; Gagaoua, M.; Barba, F.J.; Zhang, W.; Lorenzo, J.M. A comprehensive review on lipid oxidation in meat and meat products. Antioxidants 2019, 8, 429. [CrossRef] [PubMed] 
79. Villalobos-Delgado, L.H.; Caro, I.; Blanco, C.; Bodas, R.; Andrés, S.; Giráldez, F.J.; Mateo, J. Effect of the addition of hop (infusion or powder) on the oxidative stability of lean lamb patties during storage. Small Rumin. Res. 2015, 125, 73-80. [CrossRef]

80. Cieśliński, M.; Idowski, P. Application of common hop in medicine and cosmetology. Pol. J. Cosmetol. 2003, 6, 188-192. 